\title{
Ativirarama Pandyan's Tamil Life of Naidatha
}

\section{TRANSLATOR'S NOTE AND TEXT}

Ativirarama Pandyan, king in the far southern city of Tenkasi in the second half of the sixteenth century, gives his own version of the same passage from Shriharsha translated in the previous chapter but in a Tamil style rich and complex enough to rival its Sanskrit model. His Life of Naidatha is the key work in the Tenkasi Renaissance, arguably the first fully modern moment in Tamil literature. Together, both Ativirarama and his brother Varatungarama produced a library of masterpieces in Tamil, and their court was crowded with other gifted and innovative poets. In their works, we can observe experiments with highly individualistic and personal sensibilities, a radically ironic tone vis-à-vis the older tradition, a new empirical interest in the natural world, and a hypertrophied imaginative aesthetics.

ATIVIRARAMA PANDYAN'S LIFE OF NAIDATHA (4.107-23)

"Whatever is inside will always rise up

to the face. To read the signs

and state these matters in words is a great

talent: that's what messengers are for!

No one knows with the clarity

that is yours. So save me, sweet goose

of fine feathers, before I wither away.

Go now, and fast." (4.107)

She spoke openly, her voice enough

to make the cuckoo ashamed, and sweeter

by far than ambrosia or liquid sugarcane

or the honey in a flowering branch. 
The goose saw into her heart and was glad. He looked at her, drinking her in with his eyes, as he spoke these measured words. (4.108)

"Ah, you whose full breasts are budding with the pale signs of yearning and luminous as cinnabar, though they've brought your tiny waist to the breaking point, all that you've said is utterly true. I don't think there's any need to broker a meeting of the minds. Both Nala and you are ill at heart with love. It's all the work of Desire, who is also spreading the word. (4.109)

When that king of all the worlds asked us which woman is the loveliest in this world bounded by the ocean and in the Nether World and the world of the gods, we of course said it was you. You found your way into his heart by following the arrow the Love God fired. Lady with eyes like the innocent doe: have you forgotten? Or are you merely pretending not to know? (4.110)

$\mathrm{He}$, the warrior king, wants to paint your portrait. He's collected many precious stones and polished them for this collage, each for one of your perfect features. ${ }^{1}$ But it's not so easy. He grumbles: 'This damned canvas is not wide enough to paint her breasts,' or 'The tip of my paintbrush is nowhere near fine enough to paint her waist.' He's frustrated: deep psychic despair. All he can do is stare, unblinking, yearning. (4.111)

This is what he says-the king whose honed spear cut his enemies to pieces and spread a feast for kites, hawks, and whole flocks of crows-'You are the breath of my life, and you are the only remedy for the sickness of desire that has possessed me with all the suffering that entails.' He thinks this thought in misery, with joy in his heart. (4.112) 
This is that same person who is Death

to his enemies, his toenails polished to a glossy gleam

by the crowns of alien kings, and who is so dense

with beauty as he rides his huge elephant to victory

that men can't bear it and wish they were women.

Now he's a shadow of himself, and all five

of his senses hunger for nothing

but you. (4.113)

Listen to me, woman whose is hair is so dark

it makes the rain cloud look pale, woman

of dancing earrings: It's hard to say whether

he's been reduced to this state by the frontal attack

of the Love God with his five arrows dark with wasps,

honey-bees, and black beetles, or whether the white rays

pouring from the moon have undone him-since every time

he sees them, his body is further overwhelmed. (4.114)

The Love God keeps shooting long arrows of flowers from his sugarcane bow at this king. That's one thing. But beyond that, Desire has also apparently stolen his good character. It's reached the point where if he had to do something really wicked in order to lie on your breasts, he'd do it without thinking. Whatever deep wisdom he once had is gone. He's so unhinged by love that he would feel no shame at becoming your abject slave. (4.115)

He stares at your beautiful body, starkly visible in his mind. He's losing his grip, his very bones melting down. He throws himself at your young breasts. Then he decides you must be angry and, as if trying to appease you, laughs out loud. But when he sees you fading away into empty space, he rushes after you like a lunatic, awareness shattered, splintered, lost. (4.116)

He's the wild elephant of Nishadha who's crossed over a vast ocean of enemy kings with spears reeking of rotting flesh. No one could stop him. Now he's drowning in the waves of the river named 'Far From You,' with no place to stand. God help us! He's passing out. Lady with the bow-shaped brow: it's up to you now. Don't let him sink to the final stage. (4.117)

Kings who fought him now sleep in the courtyard of his palace, using their palms as pillows. We know he's a lion 
among men when it comes to war. But look what's happened to his mind, look at the state he's in. That's why he sent me as his messenger to you, lady with breasts high as the mountain slopes. But don't worry. It's all over. You've won this destiny by whatever you did, both of you, in some former life. (4.118)

Murugan's spear, the infant moon that three-eyed Shiva wears on his head, the serpent that Vishnu, husband of Shri, has taken for his bed-all these you have stolen and made them over as your eyes, your bright forehead, and your wide loins. Is it, then, any wonder that you also robbed Nala, that lord of elephants in heat, of his heart? (4.119)

'Golden girl, you who are the immortal sweetness of speech, voluptuous goddess of the lotus: how could I imagine sketching subtle sandal-paste designs anywhere but on your luscious breasts, so heavy that your waist, sleek as a streak of lightning, has been worn away and may well snap?' That's what your king said to me in a garden buzzing with bees, so that I could tell you. (4.120)

It will be my task to shake my wings after my dip in the Ganges of the Sky, to sprinkle you with a cooling drizzle and in this way to undo your inevitable exhaustion after making love in every possible passionate position. That time is near, very near. (4.121)

I'd better go now, woman whose long black eyes are deadlier by far than any lethal spear or fine-honed sword, deadlier than Death himself or the fatal poison that arose from the sea. While I'm rapidly wending my way to the king, you mustn't worry. I promise you he'll soon be riding his regal chariot straight to your chambers, and he'll be here before you know it, aflame with hunger for your dazzling breasts. (4.122)

So I'll be off, with your permission, to Nishadha, where conches, heavy with child, drift through the channels in the fields and give birth to pearls on the golden inner ring of the lotus, and then white herons 
perch over them, certain that these are their eggs." Thus spoke the all-too-innocent goose, and Damayanti of the long eyes sharp as swords gently stroked its wings and, courteous though eager with desire, said, “Go.” (4.123)

\section{HEARING AND MADNESS: READING ATIVIRARAMA PANDYAN'S LIFE OF NAIDATHA}

\section{N. Govindarajan (Near Reader)}

Ativirarama's Life of Naidatha is not just another version of the story of Nala and Damayanti. It is a Tamil version of Shriharsha's Sanskrit Life of Naishadha, but this Tamil poem does not follow the chapter divisions of its Sanskrit model. This is to good effect, and Ativirarama's version seems more logical and coherent than Shriharsha's. Indeed, the telling is straightforward and simple. It begins with a description of Nala's country and city, followed by an account of the two lovers' romance, how they overcame all obstacles to marry each other, and their subsequent happy marriage.

The passage translated here is from the fourth chapter of Life of Naidatha. This chapter narrates the errands of a goose as a go-between for Nala and Damayanti, including various dialogues between the three characters. The first is between Nala and the goose. Ativirarama breaks this dialogue into small units: Nala's meeting with the goose; the goose's portrayal of the matchless beauty of Damayanti to Nala; Nala's request that it act as his go-between; and the goose's departure on its mission. In this first dialogue, the main narrator is the goose, and Nala is a passive listener throughout. The second dialogue is a long exchange between the goose and Damayanti. After hearing about the beauty of Nala, Damayanti decides to marry him and asks the goose to convey her love to him. But the goose, before flying off, tells her that Nala is already in love with her and actually has been longing for her. Our selection consists of seventeen verses from this second dialogue in which the goose does most of the talking.

Hearing. When does love begin? The first treatise on Tamil grammar and poetics, the Tolkāppiyam, composed during the early centuries of the Common Era, suggests that love starts in the eyes, when the eyes of the hero and the eyes of the heroine meet, and especially once they can see the acceptance of love in each other's eyes. It is the eyes that initiate love, and it is the eyes that also acknowledge it. The Tolkāppiyam portrays this process as a subtle dialogical act, although no words are actually uttered. Sight is a soundless condition for and an expression of passion, so much so that another classical Tamil text, the Tirukkural, says that when two pairs of eyes meet and accept each other, words are useless. 
In Life of Naidatha, love begins in a different way. It starts with words, the words of a goose. The goose promises to Nala that he'll paint his great beauty in the middle of her mind. The goose also describes Damayanti to him so effectively that Nala can see her completely with his mind's eye. Nala then says, in a passage that is not translated in this chapter:

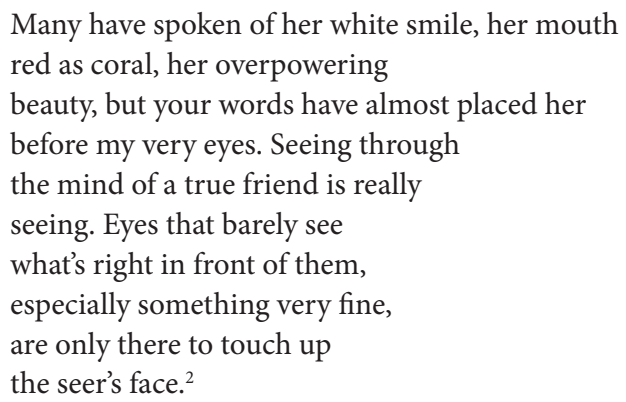

This image of Damayanti in Nala's mind comes not from seeing but from hearing. Nala sees Damayanti right in front of him as he hears the goose speak. Apt words and astute ears become key in this context. A visual image is drawn inside Nala's mind by the goose's words. Hearing enables and then enhances what the mind's eye sees. This seems to be a deliberate break from earlier Tamil poetic models, one that may be influenced by Tamil Tantric culture.

In Tamil Tantric culture, sound has many important potentials and consequences. This is because the Goddess resides in sound, and in high-level Tantric practice, she inhabits sound to the point of indistinguishability: the Goddess is sound. The tenth-century Tirumantiram, the seminal text of the Hindu Tantric tradition, proclaims that the Goddess is omkäri, the "Om" sound; she is also hrimkäri, the "Hrim" sound. Repetition and rearrangement of particular sounds will reveal this hidden presence of the goddess. But how to repeat and rearrange these sounds is known only to a few. Only a competent guru will know this secretcoded grammar of language. Such a guru can transmit the properly arranged sounds directly into the ears of others, and their own minds will then visualize the image of the Goddess.

Ativirarama seems to assume such Tantric ideas and practices in his work. As we see in the verse just quoted, the goose speaks about Damayanti to Nala and vice versa. Nala has heard of her earlier. Many have spoken of her "white smile." They have spoken about her overpowering beauty. But only the words of the goose can make her appear before his mind's eye. In other words, the goose acts like a Tantric guru in this passage. Just as a skillful guru perceives the world better than others, carefully selects what is best for his students in that context, and also knows how to impart that to his students, so does the goose. Nala, in turn, acts like a Tantric practitioner who can see the Goddess thanks to his guru's accurate instructions. As Shulman has said elsewhere, "A very ancient South Indian 
notion of the pragmatics of poetic speech has merged with the Tantric practice of phonic magic." 3

In the selection that opens this chapter, Nala tries to impart substance to his initial mental image of Damayanti by painting her portrait. Additionally, he collects many precious stones - one for each of her perfect features - and polishes them to use as ornaments for the painting. In the end his efforts to paint Damayanti fail:

"The tip of my paintbrush is nowhere near

fine enough to paint her waist."

He's frustrated: deep psychic

despair. All he can do is stare,

unblinking, yearning. (4.111)

Here Ativirarama goes beyond anything in Tamil Tantric culture. In Tantric practice, once the image is evoked in the mind, it becomes stable and lives forever inside. Nala's mental image of Damayanti is unstable, and there is a constant rush of images in his mental "inscape," even as some fade away into empty space:

He stares at your beautiful body, starkly visible

in his mind. He's losing his grip, his very bones

melting down. He throws himself

at your young breasts. Then he decides

you must be angry and, as if trying to appease you,

laughs out loud. But when he sees you fading away

into empty space, he rushes after you like a lunatic,

awareness shattered, splintered, lost. (4.116)

For Ativirarama, the Tantric version of the metaphysical stance of nonduality or unity with the divine consort is set aside by a constant and conscious notion of split, or duality. Nala is "drowning in the waves of the river named / 'Far From You"” (4.117), and the goose urges Damayanti to save him.

Madness. E. Valentine Daniel has said that in the Tamil worldview, "knowledge about the other, or object knowledge, is but an extension of self-knowledge." Selfknowledge attempts to know the other by establishing a relationship of sameness. In other words, it tries to know the self by seeing itself in the other. "At the point at which object knowledge is completely incorporated or engulfed in this manner," adds Daniel, "not only is there no longer object knowledge, but there is also no longer a self which is defined against object knowledge. What remains is pure knowledge." ${ }^{4}$ But what happens when self-knowledge, rather than making a relationship with the other, comes about through distinguishing the self from the other? Is a relationship with the other still possible? And what happens when selfknowledge tries to fit the other, conceived in this manner, into its own phenomenal world? It is here that Life of Naidatha moves into the complicated Tamil world of knowing and its aftermath. 
In both processes, according to Life of Naidatha, the ill-conceived other makes bare the rigidity of the projecting self and disequilibrates the resulting relationship between the self and its world. Nala's self-knowledge has conceived Damayanti, and "Damayanti found her way into his heart" (4.110). She is the breath of his life (4.112). Now she is in Nala's world. It is the world of valor, firmness, blood, flesh, victory, and so on. He is the king of all the worlds (4.110), "the king whose honed spear / cut his enemies into pieces and spread a feast / for kites, hawks, and whole flocks of crows" (4.112). He is "Death / to his enemies, his toenails polished to a glossy gleam / by the crowns of alien kings" (4.113). Likewise, "he's the wild elephant of Nishadha who's crossed over a vast ocean / of enemy kings with spears reeking of rotting flesh" (4.117), and "he's a lion / among men when it comes to war" (4.118). But Damayanti slowly deprives him of all such embodiments, even though she is also the only cure to his disease:

"You

are the breath of my life, and you are the only remedy

for the sickness of desire that has possessed me

with all the suffering that entails." He thinks

this thought in misery, with joy in his heart. (4.112)

Nala's good character is stolen, and "Whatever deep wisdom he once had / is gone" (4.115). His kingliness is gone, and he has become an "abject slave" to Damayanti (4.115). He is no more a king, he is not even "Nala" anymore. Everything about him has been destroyed by her. "He's losing his grip, his very bones / melting down" (4.116). He is like a "lunatic, / awareness shattered, splintered, lost" (4.116). "He's passing out" (4.117). "He’s frustrated: deep psychic despair" (4.111).

Certainly madness has overtaken him. But why? In Tamil culture, any woman who has come of age is thought to be filled with sacred power, anaik $u .^{5}$ This sacred power is an invisible and ever-potent force. It resides inside women and is always at work in them. "Ananku is the power of fertility inherent in woman and it represents a value more significant to her affines, primarily to the men-folk, than to herself." ${ }^{\prime \prime}$ In the Tamil notion of femininity, anank $u$ is sacred yet dangerous. Ativirarama makes a secret alliance with the ancient tradition of anaikku. Damayanti or perhaps her very own "sacred power", the ananiku in her, pervades the surrounding atmosphere. Damayanti's hair is so dark that it makes the rain cloud look pale (4.114), "her voice [is] enough / to make the cuckoo ashamed, and sweeter / by far than ambrosia or liquid sugarcane / or the honey in a flowering branch" (4.108). Usually a dark color symbolizes fertility in Indian culture. In Tamil love poetry, this color is inherent in the heroine. Damayanti's potency has taken possession of the whole cosmos and enslaved all of it as her own. She turns Nala's environment into an enemy, acting against him.

The goose wonders whether Nala's state of deprivation might have been caused by "the white rays / pouring out of the moon" (4.114). Ativirarama draws our 
attention to the insanity of Nala in a way that highlights Damayanti's power. Her ananiku possesses Nala. "He throws himself / at your young breasts," the goose tells Damayanti (anainku is often said to reside in the breasts of a young girl; 4.116). Then, according to the goose, Nala decides "you must be angry and, as if trying to appease you, / laughs out loud" (4.116). In his madness Nala becomes a poet (4.120). He has not even a place to stand (4.117). Nala is dying, although his death is not physical, but rather the uprooting of his own being. At the same time, Damayanti's power over Nala is also benevolent and protective, and Nala knows this too (4.112).

The goose foresees a good future for Nala. In that future, Damayanti will unite with him. Her power will be pacified. On that very occasion, the goose will come again and, after dipping in the Ganges of the sky, it will shake its wings and sprinkle her with a cooling drizzle to alleviate her inevitable exhaustion (4.121). This sprinkling will, once again, rearrange their respective worlds, bringing them and their love into an equilibrium and allowing them to live peacefully and eternally.

Medicine for Poets. When Ativirarama Pandyan, the author of Life of Naidatha, sent this poem to his elder brother's wife, a poetess in her own right, he probably expected her approval. Instead, she sent a sarcastic note saying that the poem was like a hunting dog that started running fast but then suddenly stopped, panting excessively and completely exhausted, without catching its quarry. This is usually taken as a note on the abrupt change of pace and style toward the end of the work, and the irregular, barking-like manner in which the later story of Nala and Damayanti (including their tragic separation and eventual reunion) is told. It may also be taken to signal a rift between an older poetic order, represented here by the family of the older brother, and new poetic ideals of the younger brother (the two, by the way, were also at war with one another). We do not know what the reaction of Ativirarama Pandyan was, but we do know that others saw in it far more than his sister-in-law did. In fact, his book has had a distinguished place in Tamil literary history since it first appeared, so much so that there is an old saying: Naitatam pulavarkkōr autatam (Naidatha is a medicine for poets). That is to say, Life of Naidatha cures whatever may afflict a poet, perhaps thanks to its combination of hearing, madness, and its promise of the goose's return, and with it, a pleasant shower from the heavenly Ganges. In this, the Tamil Life of Naidatha stands unique.

HOW WE READ

Sheldon Pollock (Far Reader)

All that glitters is gold SMASH MOUTH

The question prior to "What is sensitive reading?"- the question the title of this book implies-is the one implicit in my own title. A silly one, many would say, since reading is something, like walking, that we do without much thought once 
we learn how. Do we ask ourselves what it means to read when we sit down with our coffee and the morning newspaper? Of course not, but we might well, because it is no straightforward matter.

By "reading" I don't mean what the dictionary tells us reading is: "mentally interpreting the characters or symbols" of which written matter is composed. I mean making sense of the text made up of those characters (I will be speaking here of a literary text, but my observations are meant to apply to all texts, religious, legal, historical). And sense-making becomes more complicated, becomes more of a problem requiring second-order reflection, the further in time and space the origins of the text are from the reader. A "classical" work of Indian literature-by which I mean any work composed prior to the coming of Western colonialism and the break in Indian literary culture that colonialism effected-is perhaps the limit case of this problem. Such a work poses questions of meaning at the extreme, and in fact one use of exposing ourselves to such literature is that the lessons learned in trying to make sense of it apply to any act of reading of any text anywhere. As Heinrich Heine said of us Jews ("Jews are like everyone else, only more so"), classical Indian texts are like all others, only more so. The surfeit here is due to the fact that making sense of an Indian text requires the full range of meanings that "sense" can possess. Let me explain what I mean by this.

The morning paper comes, or appears to come, in a kind of pure presentness: it has no past (indeed, who wants yesterday's papers?). A literary work from, say, sixteenth-century south India, however, has a past; it has, in fact, what for analytical reasons we can describe as two distinct pasts. One is the deep past of its moment of creation, where the text possessed various meanings for the original audience of the work. The text also has a shallower past, the three centuries following its production, where again it possessed a range of meanings for its readers. It also of course has a present, our own direct confrontation with the work here and now.

My basic argument is that none of these meanings, those of its origin or reception or now, is a truer meaning-more closely corresponding with, or a better representation of, the essence of the text-than any other, for the simple reason that a text has no essence. The one true meaning of the text lies in none of those three readings, but rather in their sum total, in their full diversity itself. Particular readers-whether primary, traditional, or present-day-have by definition no access to that full diversity. Excavating that true meaning by assembling those readings is the work of the specialist in making sense of texts, namely, the philologist.

Accordingly, neither the "context-near" nor the "context-far" modes of reading, to adopt the idiom of the editors of this book, can ever stand independently for us philologists. We cannot read responsibly - that is, with the scholarly, even ethical, orientation of understanding not only that we impose our meaning on the world but that we must allow the world to impose its meaning on us, without which reading itself actually would become superfluous and hence meaningless-if we do not tack between them: between what a work meant in its historical moment and what it means to me here and now, with a third plane of meaning, that generated over 
the history of its reception, situated somewhere between "near" and "far." None of these meanings can simply be avoided. Presentist reading is not some optional practice; it is how we do, and must, first approach a text, which only subsequently we address more complexly. Contextualizing, or historicizing, reading, by contrast, is something we only learn to do, but once learned-and it is now universally learned-it cannot be unlearned. The meanings offered by a tradition are less often accessible to us unless we look closely. Few people, I suspect, bother any longer to read Shakespeare in the old Furness Variorum editions (which excerpts editor and commentator exegeses over several centuries), though Indianists always read, as people in India used to read, embedded in tradition. In any case, tradition has a way of seeping into our consciousness whether we know it or not; it helps constitute our prior hermeneutical situatedness, Gadamer's famous Vorurteile, or prejudgments (Shakespeare does not drop down right out of the sky to any contemporary reader, he comes trailing traditional clouds of glory). There is not only the potential for conflict among these meanings, but every likelihood of conflict. And that is so because of the inevitable cleavages in consciousness of readers as historical beings, and as a result the very different ways features of the text will address themselves to them.

For the philologist in me, then, my reading here and now-what I have taken to calling the presentist reading (a descriptor that of course applies to every earlier reading viewed in its historical moment) — can never stand alone as it is being asked to stand here. But, of course, it cannot stand together unless and until it has first tried to stand alone. For the exercise assigned to me here, however, I have to pretend to be far separated from the context of the selection: from its sixteenthcentury social-political context (which I know something about); from its cotextual context (including the various Sanskrit originals with which the Tamil work is in conversation, and the vast body of Indic literary theory it is aware of, about which I also know something); from the textual context of the selection (like every other Indianist I know what finally happens in the Nala-Damayanti story-and I know it is a poem as defined by Indian tradition, and not a historical or religious or legal document). Here I am asked to consider the text completely denuded of all these contexts, as if I.A. Richard's were handing me the poem, or it came to me on the New York subway wall as part of the MTA's "Poetry in Motion" series, or better yet, as a reading assignment in a Great Books class I will pretend I am taking as a freshman in college. What meanings can the text have for this sort of me here and now?

The fact that has primacy for me in any theoretical analysis of reading, "sensitive" or otherwise, is that my presentist reading will have an irreducible and ineluctable dimension of my historically constituted subjectivity, and for that reason will only ever access one plane of the truth of the text. The methodological question, by contrast, is only a subsidiary fact, namely that all presentist readings, if necessarily partial and equally partial, are not all equal. Some methods unequivocally reveal 
or explain more of the text to our presentist eyes than others do. This is obvious in the case of lexical and grammatical methods, where knowing (that is, knowing how to figure out) what the words mean and how they best construe is unequivocally more illuminating of the text than not knowing at all. Less obvious but potentially equally illuminating are narratological, rhetorical, discourse-analytical, and other such methods that help us to look more deeply, to seek patterns, to discover and put pressure on tensions, to excavate more systematically the world that the text is conjuring, its vision of human being.

So then, with the proviso we acknowledge that while "sensitive" reading is a fine thing, it is a partial thing, we can happily inquire into what we come to understand about our selection when we ask about, say, its narrative organization, formal features, discursive tensions, and orientation toward the world.

Poetics and Patriarchy. Like the other selections in this book, Life of Naidatha comes to me in a contemporary translation. But all translation is a form of reading (just as all reading is a form of translation) — an especially and visibly transformative form of reading. And as such it is subject to the many constraints I have already described. All the issues about subjectivity that I know I am facing when reading in general, and when reading this particular selection, had to have been faced by the translator. The text thus comes to me preread, prepresentist, so to speak; we are already_and as I claim, we are always-already-distant from the possibility of some single textual truth. (Some who argue "against world literature" tell me to learn Tamil; a noble sentiment, but remember that that only offers another plane of textual truth, and cannot bring us closer to The One Truth, because it does not exist.)

The selection is just that, a selection, and it is impossible to extrapolate, in some Auerbachian fashion, to the whole work (and beyond) since ex hypothesi I do not know the whole work. Is it possible that, as is the case in this selection, in the whole work too, and others of its genre, nothing much actually happens? Nothing at least on the surface. It is just a dialogue between a lovelorn girl and a talking bird (some theriomorphic concretization of the girl's hopes? some prefigurement even of her soul?), elaborating in multiple ways on her longing and her lover's. Just below that surface, however, a great deal indeed is taking place: the workings of overwhelming desire, assertions of political power, threats of dangerous transgressions, battles, violence, death. We seem to be in a world of poetry very different from what I am familiar with, where action occurs not so much in a narrative mode but in a figurative one: the story seems to be in the rhetoric, while rhetoric itself is part of the story. And what rhetoric!

The level of figuration here is overwhelming, comparable to nothing in literature known to me. I have seen Indian paintings in museums that seem jewelencrusted, burnished with gold, resplendent with color, and which in that sense are very like the ornamentation of this selection. In fact, the text itself seems to call 
attention to this shared aesthetic, when the poet describes the "precious stones" polished for use in the portrait of the woman, which is itself a figure of the lover's quest for union. But figures of this sort are not part of my world-no more than the ornamentation on the seventeenth-century building where I once lived in Brussels could adorn my former Mies van der Rohe apartment in Chicago. It is their very density that prompts me to think about these figures and the kind of work they are doing.

For this poet, literature itself seems to be, in some very significant measure, precisely an exploration of the outer limits of language, here of describing otherwise indescribable objects or themes: the ineffable beauty of a woman, say, or the near-death experience of unfulfilled love. Matters such as these cannot be directly expressed but can only be captured in language that somehow bends reality to its purposes. Thus, the woman's voice or hair or eyes are not meaningfully described as "beautiful": no, her "voice [is] enough / to make the cuckoo ashamed"; her "hair is so dark / it makes the rain cloud look pale"; her "long black eyes / are deadlier by far than any lethal spear or fine-honed sword." Who piles up figure upon figure? (Well, maybe more than we take time to register-or took time to register before this selection forced us to; consider now the line "its fins like blades, its milky skin and wool-grey eyes," in a Dave Eggers novel. ${ }^{7}$ )

Things figurative can get very complicated very quickly: for example, the woman's eyes, forehead, and "wide loins" are actually things she has stolen from others - the spear of Murugan, the moon of Shiva, the serpent-bed of Vishnu (gods I guess, but I am ignorant)—so she's a clever and audacious and even impious thief, too, who can steal a man's heart. In general, however, these figures remind me of standard similes I already know. Yet the poet goes further in his figuration, seeking a way to capture a thing's ineffability not only by comparison but also by hyperbole. Vassals don't just bow down to a king; they polish his toenails with the gleam of their crowns; they find him so beautiful they wish they were women. The king himself is so lovesick that the rays of moon overwhelm him like the arrows of the god of love; his very bones melt. I feel certain there is far more going on in the figuration in this text (including the last verse, which is too allusive for me to understand), and I am led to wonder if they have ancient handbooks explaining how these complex figures work.

The hyperbole of figuration is complemented by what seems to be hyperbole of description. The king is not just in love: he is utterly overwhelmed by love. But here something curious begins to show itself, in that this extreme state is repeatedly expressed by the conjuncture of political violence and sexual desire. Juxtaposed to Nala's cutting "his enemies into pieces and spread[ing] a feast / for kites" is his declaration that his beloved is "the breath of my life." The man who is "Death to his enemies" is himself dying of love; he who has crossed "a vast ocean / of enemy kings with spears reeking of rotting flesh" is now drowning in longing for his beloved. 
The hyperbole takes us into even stranger, darker areas, where we no longer feel certain that the poet is rhetorically exaggerating-where we are no longer sure this is still poetic play. How are we to take the following?

... Desire has also apparently stolen his good character. It's reached the point where if he had to do something really wicked in order to lie on your breasts, he'd do it without thinking. (4.115)

The repeated references to violence, not just legitimate violence against enemies but what to my modern mind is criminal violence, when conjoined with references to desire produce an odd concatenation, one that asks us to pause and think. Of course, the god of love, in this old and far-off world as in my own, is himself an archer (he shoots arrows, five of them, "long arrows of flowers," at the king), and so violence and desire are linked in a primal figure. But is the poet here not pushing us, especially in this last verse, beyond this innocent mythological convention?

Since I am context-far, I know nothing about any aesthetic reflection in the tradition over tensions such as that between violence and love (is the copresence of such emotions common in this literature?). More broadly, I do not know whether King Nala is characteristically prone, or somehow driven, to reckless action; whether other kings in ancient Indian literature are shown to be tempted to evil by desire; or whether the poet-who was himself a king, according to the headnote-may be reflecting on the precarious balance between public justice and private fulfillment. All I do know is the text, and this suggests-however rhetorically meant the last verse may be, for remember that a "rhetorical question" provides an answer even while not expecting one-it was perfectly possible in this world to imagine, and to fear, the most dangerous kind of desire: one embodied in an authority that can simply demand fulfilment.

As unsettling as the intimation here of unconstrained power is the poet's reduction - as I see it, who know nothing about gender relations in ancient Indiaof the woman to her sheer physicality. Of course, modern English poets I am fond of have reflected analogously on the mystery of body and soul; "love comes

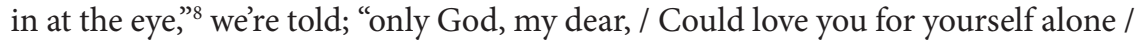
And not your yellow hair." Is it the same here? Nala has fallen in love with Damayanti only because of her physical beauty-he sought the woman who is "loveliest in this world," one whose "full breasts are budding" so much so as to bring her "tiny waist / to the breaking point" (more hyperbole for the ineffable). And it is that beauty that constitutes the sole focus, the core, of his fantasies and obsessions. The canvas of his painting is not wide enough to accommodate her breasts, his brush not fine enough to draw her waist. He stares in his fantasy at her beautiful body, throws himself at her young breasts, breasts "high as the mountain slopes," "luscious breasts, so heavy / that your waist, sleek as a streak of lightning, / has 
been worn away and may well snap." The king is "aflame with hunger" for nothing the woman possesses beyond her "dazzling breasts."

I know nothing about Indian moral thought and so the idea that physical perfection is a visible manifestation of moral perfection would not even rise to consciousness; neither would the idea, since I know nothing about Indian religions, that perhaps some perfect unity at the core of such a physical fixation could be thought to prepare the way for greater spiritual unity. A context-far reader like me will instead be inclined to see this as a sector of the long shadow of male power-here poeticized, normalized, and thereby endorsed-reducing woman to her body, a body the man can grab because he is a star; a shadow reaching back, from Yeats, and indeed, from me, here in the present, further and further into the past. The only difference between the text and me in this regard is that I can see and acknowledge that shadow-perhaps precisely, in part, thanks to such a distant text as this.

Practices of Reading and a Theory of Meaning. In the persona of a general, context-far, nonphilological reader, I have tried to offer some sense of the narrative of this selection, its figuration, dualities, political ethics, and gender dynamics. Others will read differently, probably deeper, probably better. But their senses, any more than mine, are unlikely to be borne out by the interpretations found in the deeper past. This is so because "sensitive reading" is no single thing throughout history; it discovers no truth that transcends time and necessity. The sensitive readers of old India, the sahrdayas, never read the way I have been reading here; they never attended, or described, or saw the way I have done. Like other early readers (Romans such as Servius, say) they tended not to read works as wholes, for example, instead concentrating their exegetical energies on the single verse. And the sensitivity of sahrdayas themselves was by no means self-same through time: later readers found meanings that were never shared by earlier ones, like the fifteenth-century Ramayana allegorists, whose readings would have seemed outlandish to fifth-century readers.

While it may seem self-serving to say so, then, the methodological question, whether my "sensitive" reading is sensitive enough, is not for me the important one to ask (it isn't even coherent given that "enough" is incoherent). Method is a second-order question. The primary one turns on the theory of meaning and what, therefore, according to the theoretical viewpoint I set out earlier-the scholarly, or better, philological, viewpoint-we are to do with that reading.

It is not the task of philology, or of my philology, to test my presentist understanding of the text against its meanings in the original context and its meanings over the centuries of its reception. Its task rather is to conjoin that understanding with those others. It strikes me as illogical to say that a subjective sense of a text, which (as philosophical hermeneutics has powerfully argued) is ineluctable, can be wrong. By all means let's agree with Auerbach that from his historicist 
perspective it will be "unhistorical and dilettantish." But it remains the consciousness summoned forth in me-and in every presentist reader, which means all readers everywhere, a present consciousness is summoned forth-by actual features of the text. Yet at the same time, however, that sense, however necessary a condition of understanding it is revealed to be, cannot be a sufficient one.

That is the real Ansatzpunkt of criticism, to use Auerbach's term, where we grasp that such sufficiency can be achieved not by methodological refinementsclose reading or distant, surface reading or symptomatic, formalist or discoursecritical, all of them useful, and better or worse depending on the purposes we want them to serve and the skill with which we execute them-but only by the expansive transhistorical synthesis performed by philological scholarship. You cannot become Auerbach unless you first become yourself. And even Auerbach was not the Auerbach you think, given his consistent failure even to acknowledge his ever-present presentist self and so to exorcise the ghost of metaphysicsthe reader's own historicity-that haunts historicism. While scholars are readers, readers qua readers are not scholars. They only make their present (or historicist, or traditionalist) sense. Scholars by contrast acknowledge, with the humility that comes from philological understanding, the actual, astonishing, plenitude of senses. They know, or should know (though how rarely they actually acknowledge it) that they will never discover the one true meaning of a text, that they will never finally crack the code, because there is no such meaning, there is no such code. There is only the panoply of meanings the text has evoked in readers over time. Truth lies in none of them individually, not even in their triangulation toward some single consensual meaning. It lies in the very assemblage of all of them, which the philologist holds-entirely possible if difficult though it is to hold-in a kind of nonevaluative equipoise.

My meaning, like every other, is conditioned by my consciousness as a being in history and is a consequence of the fact that that consciousness, my world, will often be radically different from worlds gone by. Learning those older meanings, by reading texts like the Life of Naidatha, helps me to understand just how different other ways of literary being-other forms of consciousness, other worlds, in short, other ways of being human-have been in the past, and thereby to grasp how I have become who I am. 